\title{
The Development of English Lessons for Work by Using the Conversation Focusing on Practical English Vocabulary in Hospitality Industry for Thai EFL Students
}

\author{
Salinda Phopayak ${ }^{1} \&$ Phanornuang Sudas Na Ayudhaya ${ }^{2}$ \\ ${ }^{1}$ Language Institute of Nakhon Pathom Rajabhat University, Nakhon Pathom, Thailand \\ ${ }^{2}$ Faculty of Humanities and Social science, Bansomdejchaopraya Rajabhat University, Bangkok, Thailand \\ Correspondence: Salinda Phopayak, 85 Malaiman Road, Language Institute of Nakhon Pathom Rajabhat \\ University, Muang Nakhon Pathom, Thailand.
}

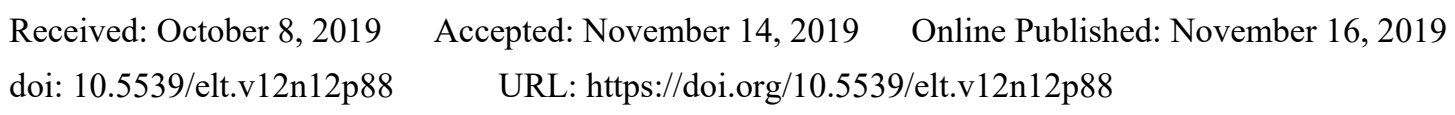

\begin{abstract}
The study investigated the use of English lessons for work by using the conversation focusing on practical English vocabulary in the hospitality industry that has any effect on the students' ability in using English conversation and vocabulary in the hospitality industry. Also, the present research explored the students' opinions toward the materials. The objects consisted of 34 Non-English major students of undergraduate of Nakhon Pathom Rajabhat University. The researcher used the paired sample t-test to analyze the students' ability in using English conversation and vocabulary in the hospitality industry before and after using the materials. Besides, the mean and standard deviation of items were used to evaluate the students' opinions toward the materials constructed. The results revealed that the efficiency score of the materials constructed was higher than the excepted criterion. Also, the students' ability in using English conversation and vocabulary in hospitality industry materials constructed at the 0.05 level, and the students' opinions toward the materials constructed were generally high.
\end{abstract}

Keywords: communication skills for workplace, material development for ESP courses, supplementary English lessons for work in hospitality industry, terminology words

\section{Introduction}

Since, 2016, the policy of Thai government of the raising English standards in higher education institutions as the reform movements in the teaching developing English language teaching and learning, students should have knowledge and ability to use English as a tool to international knowledge and keep pace with the world. (Announcement of the Higher Education Commission The policy of raising English standards in higher education institutions in 2016). Thus, the institution of education must set the policies and goals to raise English standards in all curricula and all levels of education. This is a good way to improve the skills of students using English as a graduate with good academic and professional skills and English communication skills at working level.

As an instructor at Language Institute of Nakhon Pathom Rajabhat University (NPRU), I found that the students are lacking English speaking skills. Because of studying by using the non-specific instructional material. Despite, learning with the general subject of Basic English or English for communication is not sufficiency knowledge for the students to prepare their selves for working in the future. Moreover, practicing English in real life and effectiveness needed to work in the future. Therefore, the Language Institute of NPRU is created an elective course, English for Work course is a required part of the curriculum, to help the students be prepared for their career in the future. (Curriculum in 2017). This course aimed to develop English vocabulary and expressions used in the field of business English and improve their English skills in authentic situations.

To provide the new stage of student's career life, General English cannot reach the goal for the students to improve their communicative skills at workplace under investigation, the Supplementary English Lessons for Work by Using the Conversation Focusing Practical English Vocabulary in Hospitality Industry were implemented and assessed. The researcher considers that the English Lessons for Work is an alternative material on teaching this elective course, English for Work. 


\subsection{Purpose of the Study}

The purpose of this research were 1) to develop and test the efficiency of the English lessons for work by using the conversation focusing on practical English vocabulary in hospitality industry for Thai EFL students, 2) to compare students' ability in using English conversation and vocabulary in hospitality industry before and after using the materials constructed, and 3) to investigate the students' opinions toward the materials.

\subsection{Research Questions}

The research addressed these questions:

1). Do the English Lessons for Work by Using the Conversation Focusing on Practical English Vocabulary in Hospitality Industry improve the students' communication skills?

2). Does teaching Communicative English for work through the English Lessons for Work by Using the Conversation Focusing on Practical English Vocabulary in Hospitality Industry have a significant effect on Thai EFL students?

3). What are the students' attitudes towards the use of the English Lessons for Work by Using the Conversation Focusing on Practical English Vocabulary in Hospitality Industry in the classroom?

\section{Literature Review}

\subsection{The Importance and Chracteristics of English for Specific Purposes (ESP) and Syllabus Designing for ESP Course}

The important of English for Specific Purposes (ESP) for English language learning. According to Robinson (1980), ESP has developed a new concern for the needs and feelings of the learner rather than requirements of an externally imposed syllabus. Hutchinson and Waters (1987) mention that ESP should be seen as an approach. It is an approach to language learning, which is based on learners' need. As Sinha and Sadorra (1991) postulate, "ESP simply means learning for a very specific goal rather than for a very general or board purpose." ESP aims to meet the needs of particular learners. As Robinson (1980) indicates, an ESP course is purposeful and aimed at the successful performance. This should be based on an analysis of learner's needs. Nevertheless, ESP course may differ from another in its selection of skills, topics, situations, functions, and language. Robinson (1991) indicated that ESP as an enterprise involve training and practice and draws up three major realms of knowledge: language, pedagogy and the people's participant specialist areas of interest. Thus, ESP should be employed to help the students in communicative skill in workplace since ESP consists of language skill in workplace setting that require special training. Especially, English includes not only knowledge of a specific part of the English language, but also competency in the skills required to use this language, as well as sufficient understanding of the contexts within which it is situated (Brumfit, 1977). An ESP syllabus is a guideline and context learning content for the students to plan their map of the course. Likewise, Robinson (1991) mentions that "ESP course design is the product of a dynamic interaction between a number of elements: the results of the needs analysis, the course designer's approach to syllabus and methodology, and existing materials. Robinson concludes that there is a wide range of choices for course designers, although they may be constrained by past practices, institutional exigencies, and personal predilections.

\subsection{The Selection of Vocabulary for Teaching in ESP Course}

A technical word is understandable specific to a particular topic. Field or discipline. It can be learned and understood by studying the field. Strevens (1973:223) states that learners who know the scientific field may have little difficulty with technical words; but the teacher who doesn't may have a great deal. Besides Dudley-Evans and St. John (1998:81) claim that it is important that both the teacher and the students appreciate that this vocabulary is acting as carrier content for an exercise and it is not the real content of exercise. Nation, Warring (1997) recommens that to prepare the vocabulary component of a language course, teachers should have basic words to refer to and they need to judge whether a particular word deserves attention or not. In addition, the specialized vocabulary should be put to the centre of the ESP classroom to help learners achieve their goal: to communicate fluently in a job-related real situation in a multinational surrounding. On the contrary, English should be presented in authentic contexts to make the learners acquainted with the particular ways in which the language is used in functions that they will need to perform in their fields of specialty or jobs (Fiorito).

In this study, the researcher selected the vocabulary to make the conversation by surveying the frequency of vocabulary used in hospitality industry with the hotel staff within three departments including; front office staff, food and beverage staff, and housekeeping staff those who work in the 5-star hotel in Thailand. Then, the researcher developed the materials based on authentic vocabulary used in the hotel industry. 


\section{Method}

\subsection{Research Design}

The methodology used in this study was a Pre-Experimental Design which was a quantitative research study. The type of study was pre-experimental research for the one-group dependent pretest-posttest method.

\subsection{Participants}

The participants were selected by simple random sampling technique, consisted of 34 general management students in the 3rd year from the Faculty of Management Science, Nakhon Pathom Rajabhat University. Their ages ranged from 20 to 23 years old. They registered in English for Work course during the second semester of the 2018 academic year.

\subsection{Research Instruments}

The research instruments were operated: the 8 units' English lessons for work by using the conversation focusing on practical English vocabulary in hospitality industry, the pretest and posttest papers and the questionnaire to survey the satisfaction of the participants. Moreover, the research instruments were developed and evaluated the content validity by the specialists. The study were improved and tried out within group of 3 and 10 students before the true implementation. The teaching material was designed and integrated the communication skills; listening, speaking, reading and writing focusing on practical the conversation and vocabulary used in hospitality industry. The material including unit exercises and role-play activities based on the situation provided and related to the hospitality work. The researcher selected the vocabulary to make the conversation by surveying the frequency of vocabulary used in hospitality industry with the hotel staff within three departments including; front office staff, food and beverage staff, and housekeeping staff those who work in the 5-star hotel in Thailand. Then, the researcher developed the materials based on authentic vocabulary used in the hotel industry. The contents of each unit included; Unit 1 Welcoming guests, Unit 2 Dealing with guests request, Unit 3 Problem and complains, Unit 4 Giving directions, Unit 5 Offering help and giving advice, Unit 6 Food and beverage services, Unit 7 Housekeeping services and Unit 8 Using the telephone.

The English achievement test was used as pretest and posttest to determine students' ability on using the conversation and English vocabulary in hospitality industry. The achievement test consisted of 40 multiple-choice questions. The test made use of the level of knowledge (Valette: 1977) to examine the development of the students' communication skills. To collect the data, the researcher used SPSS program to process the gathered data by pre-test and post-test. In addition, the questionnaire was used to survey the students' opinions toward the material constructed in classroom.

\subsection{Procedure}

The research conducted in the second of the 2018 academic year. The students were enrolled in English at Work course. This course aimed to develop English vocabulary and expressions used in the field of business English and improve their English skills in authentic situations. The students met in class once a week- three hours. The length of the semester was 16 weeks. The student was conducted over a period of 14 weeks. Before the study, the researcher asked the students to do an English Achievement test of ability to use the conversation and English vocabulary in hospitality industry before studying, this pre-test consist of 40 items and take 60 minutes for testing. Then, the researcher clarified the study objectives and explained to the students how to learn by using English lessons for work focusing on practical the conversation and English vocabulary used in hospitality industry. After that, the teaching was done until 8 lessons. The researcher asked the students to do the posttest to compare their ability on using the conversation and vocabulary in hospitality industry. The questionnaire for student's opinions toward the English lessons for work by using the conversation focusing on practical English vocabulary in hospitality industry was used in order to check the effectiveness of the material constructed on the communication skills of the students.

\subsection{Data Collection and Data Analysis}

The data collection procedure was divided into three stages. The first stage was before the development of the materials, during the implementation, and after the implementation. The statistics used to analyze data from this study were the basic statistics such as percentage, mean, and standard deviation. The efficiency of course materials was analyzed by E1/E2 at the level of 75/75. The pretest and the posttest data were analyzed by $\mathrm{t}$-test and the evaluation of the effect size.

\section{Results}

The results from the implementation of the English Lessons for Work by Using the Conversation Focusing on 
Practical English vocabulary in Hospitality industry was shown in the Table 1.

Table 1. Mean and S.D. and range of average scores of 8 units

\begin{tabular}{lllllll}
\hline Unit & Unit Title & Unit score & Mean & S.D. & Percentage & Range \\
\hline 1 & Welcoming Guests & 10 & 7.2 & 0.90 & 70.29 & 8 \\
2 & Dealing with guests requests & 10 & 7.3 & 1.06 & 73.52 & 4 \\
3 & Problems and complains & 10 & 7.8 & 0.71 & 70.88 & 7 \\
4 & Giving directions & 10 & 7.6 & 0.91 & 76.76 & 2 \\
5 & Offering help and giving advice & 10 & 7.1 & 1.24 & 71.17 & 6 \\
6 & Food and beverage services & 10 & 7.4 & 1.02 & 74.70 & 3 \\
7 & Housekeeping services & 10 & 7.7 & 1.00 & 77.94 & 1 \\
8 & Using the telephone & 10 & 7.2 & 1.00 & 72.05 & 5 \\
\hline
\end{tabular}

Table 1 shows that unit 7 housekeeping service gained the top rang of mean score at $77.94 \%$, the second range was unit 4 giving directions at $76.76 \%$, and the third was unit 6 food and beverage at $74.70 \%$. The fourth was unit 2 dealing with quests requests at $73.52 \%$, then the fifth was unit 8 using the telephone at 72.05 , and unit 5 was the sixth. The two rang were unit 3 problems and complains at $70.88 \%$ and unit 1 welcoming guests at $70.29 \%$. The difference of sample group on the ability of using the conversation and vocabulary in hospitality industry was shown in Table 2.

Table 2. Mean, S.D. and t-test of student's ability on using the conversation and vocabulary in hospitality industry

\begin{tabular}{lllllll}
\hline test & $\mathrm{n}$ & mean & S.D. & $\mathrm{t}$ & $\mathrm{df}$ & Sig. \\
\hline Pretest & 34 & 21.29 & 8.63 & & & \\
Posttest & 34 & 31.11 & 10.34 & 16.23 & 33 & $0.00^{*}$ \\
\hline
\end{tabular}

Table 2 shows the student's ability in using the conversation and vocabulary in hospitality industry from the pretest and posttest. After learning by the materials constructed was significantly higher than before their entry at the 0.05 which pointed to the difference of the student's ability on using the conversation and vocabulary in hospitality industry score before and after learning. The students' opinions toward the English Lessons for Work by Using the Conversation Focusing on Practical English vocabulary in Hospitality industry was shown in Table 3.

Table 3. Mean and S.D. of participants' opinion toward the English lesson for work by using the conversation focusing on practical English vocabulary in hospitality industry

\begin{tabular}{lll}
\hline Statement & Mean & Level of Agreement \\
\hline
\end{tabular}

\section{Form}

The alphabets were clear and easy to read.

3.99 High satisfaction

The activities were presented in each stage was clear.

$3.84 \quad$ High satisfaction

\section{Contents}

The difficulty of the contents was consistent with my learning level. $\quad 4.00$

The contents were related to the class's time. 3.86

High satisfaction

The contents were useful and the knowledge could be used to develop 4.04 my communication skills.

High satisfaction

High satisfaction

\section{Activities}


List the vocabulary is an activity that allows me to learn and use the 3.95 conversation and English vocabulary in hospitality industry.

Listen to the dialogue is an activity that allows me to practice and understands the conversation and English vocabulary in hospitality industry.

Use vocabulary and expression is an activity that allows me to practice and writes the conversation and English vocabulary in hospitality industry.

Create the dialogue and role-play is an activity that allows me to practice and use conversation and English vocabulary in hospitality industry.

All activities were compatible.

\section{The benefits}

The lessons can improve my speaking ability.

The lessons increase the varieties of vocabulary used in the 3.82 hospitality industry work.

Total
High satisfaction

High satisfaction

High satisfaction

High satisfaction

High satisfaction

High satisfaction

High satisfaction

High satisfaction

The students' opinion toward the English Lessons for Work by Using the Conversation Focusing on Practical English Vocabulary in Hospitality Industry constructed in the class was clearly stated in Table 3 that the students had positive high satisfaction in the appropriateness of the contents were useful and the knowledge could be used to develop my communication's skills (4.04), and for the benefits of the lessons, the students felt that they gained more English knowledge and skills from the lessons in the lessons can improve my speaking ability (4.02). Besides, the students had positive satisfaction in the activity as list the vocabulary is an activity which let me learn and use the conversation and English vocabulary in hospitality industry (3.95), and the alphabets were clear and easy to read (3.99). To overall of the materials constructed was at high level with the total mean of 3.91

\section{Discussion}

\subsection{Major Findings}

This study focused on the development of the supplementary English lessons for work by using the conversation and English vocabulary that created from the frequently used in the hospitality industry, in the area of hotel jobs, which encouraged students to practice English communication more in listening, speaking, reading and writing the conversation by using the English vocabulary in pairs and role-play. In addition, the English vocabulary was elicited from the hotel staff, hotel specialists, and the frequently words used in hospitality industry terminology. Moreover, the contents and actives approach in teaching and learning worked effectively with teaching English for Work according to the material constructed evaluation. Brumfit (1977) mentioned that ESP should be employed to assisst the students in communicative skills in the workplace since ESP consists of language skills in the workplace setting that require special training. Especially, English includes not only knowledge of a specific part of the English language, but also competency in the skills required to use this language, as well as a sufficient understanding of the contexts within which it is situated.

\subsection{Implecation of the Study in the ESP Class}

The success of the development of the supplementary English lessons for work by using the conversation focusing on practical English vocabulary in hospitality industry was from the vocabulary survey was provided realistic information for the development of the conversation constructed. The activities in the materials constructed were appropriate with the students learning level. As Sinha and Sadorra (1991) mentioned that the ESP course may differ from another in its selection of skills, topics, situations, functions, and language. The same as Robinson (1991) indicated that ESP as an enterprise involves training and practice and draws up three major realms of knowledge: language, pedagogy and the people's participant specialist areas of interest. Thus, the achievement of the students in the experimental group after learning by using the materials constructed was higher than before their learning. Moreover, the satisfaction of classroom activities was at high level. 


\subsection{Teaching Materials}

From the results mentioned in the previous study, the majority of the participants need to improve their listening and speaking skills by using the supplementary of English lessons for work by using the conversation and English vocabulary that created from the frequently used in the hospitality industry because they can enhance their knowledge as much as they need. In addition, they possibly practice their English and refer their knowledge when they confront with the communication problems.

\subsection{Limitations of the Study}

The participants in this study were 34 general management students in the 3rd year from the Faculty of Management Science, Nakhon Pathom Rajabhat University. Thus, the findings might not be generalized to other students.

\subsection{Recommendations for Further Studies}

Further studies may explore needs in English reading and writing skills for communication in the workplace, by using other data gathering techniques such as focus groups, observation, and surveys which help to gain more accurate and detailed information about the specific course.

\section{Conclusion}

According to the previous study, the suggestion from the students revealed that the English lessons for work by using the conversation focusing on practical English vocabulary in hospitality industry is very important for the students. The lessons constructed should be consisted of four skills of English to enhance English communication competency and relate to real work situations. Therefore, teaching and learning activities should assist students to become more competent in English communication skills. For further study should investigate learners at a different level in other fields of study to reflect their opinions about teaching materials created for the ESP courses. To conclude, it is recognized that instructed related to the jobs relevant in their career for future provide language learners with knowledge, skills, and attitudes that are required.

\section{Acknowledgments}

I would like to express my gratitude to the Research and Development Institute of Nakhon Pathom Rajabhat University for partly funding this research project and also, I hope that this contribution will assisst our students to succeed in their learning.

\section{References}

Allen, E., \& Vallette, D. (1977). Classroom Techniques : Foreign Language on English as a Second Language. New York. Harcourt Brace Javanovich Inc.

Blue, G., \& Harun, M. (2003). Hospitality language as a professional skill. English for Specific Purposes, 22, 73-91. https://doi.org/10.1016/S0889-4906(01)00031-X

Brown, T., \& Lewis, M. (2003). The ESP project: analysis of an authentic workplace conversation. English for Specific Purposes, 22, 93-98. https://doi.org/10.1016/S0889-4906(01)00050-3

Brumfit, C. (1984). Communicative Methodology in Language Teaching. Cambridge: Cambridge University Press.

Dudley-Evans T., John, M. (1998). Developments in ESP. A Multi-disciplinary Approach. Cambridge University Press.

Fiorito, L. (2017). Teaching English for Specific Purposes (ESP). Retrived 7 July, 2017, from http://www.usingenglish.com/teachers/articles/teaching-english-for-specific-purposes-esp.html

Hutchinson, T., \& Waters, A. (1994). English for Specific Purposes. Cambridge: Cambridge University Press.

Nation, I. S. P. (1990). Teaching and Learning Vocabulary. New York: Newbury House Publishers.

Nation, I. S. P. (2003). Learning vocabulary in another language. Cambridge: Cambridge University Press.

Nunan, D. (1989). Designing Tasks for the Communicative Classroom. Cambridge: Cambridge University Press.

Nunan, D. (1999). Second Language Teaching and Learning. Boston: Newbury House Publication

Nunan, D. (1991). Communicative task and language curriculum. TESOL Quarierly, 25, 279-295. https://doi.org/10.2307/3587464

Likert, R. (1932). A Technique for the Measurement of Attitudes, Archives of Psychology, No. 140. Paris: The University of Western Ontario. 
Office of Higher Education Commission. (2016). Thailand Education Policy. Bangkok

Robinson, P. (1991). ESP today. Oxford: Oxford University Press.

Sinha, A. C., \& Sadorra, L. C. (1991). A Primer on ESP for Teachers of English. Manila: The De La Salle University Press.

\section{Copyrights}

Copyright for this article is retained by the author(s), with first publication rights granted to the journal.

This is an open-access article distributed under the terms and conditions of the Creative Commons Attribution license (http://creativecommons.org/licenses/by/4.0/). 